\title{
LIBRARY USE FROM DISCIPLINE CONTEXT: ANALYSIS OF PERSONAL TRAITS AND ATTITUDES OF UNDERGRADUATES
}

\author{
Anura Karunanayake (1)
}

(1) I Deputy University Librarian Fiji National University, Suva, Fiji Islands, anura.karunanayake@fnu.ac.fj

\begin{abstract}
This paper identifies the patterns of library use of undergraduates from discipline context based on their personal traits and attitude or Mode of library use. Medical and Arts undergraduates' personal traits and attitudes are examined. Twelve variables which represent personal traits and six attitudes are observed. Descriptive analysis is used to measures the personal traits by mean values and Chi-square and ANOVA tests was used to identify the statistical differences of attitudes by disciplines. The results found that personal traits make them different in libraries. The students in the two discipline areas turned
\end{abstract}

\section{Introduction}

Library use of undergraduates affects from Social, Cultural, Geographical, Discipline, Academic years, Gender, Cognitive, Emotional aspects of contextual situations. Assessment of library use from contextual aspect is essential for the improvement of academic libraries. Hence, this paper selects "discipline context" to identify the discrepancy in library use based on 1) Personal traits of undergraduates, 2) Attitudes or mode of library use. To understand how these two aspects related to library use, a paper survey was conducted from a sample of undergraduates. Relationship be-tween discipline context and personal traits and attitudes in library use has rarely been investigated in pattern studies. Data analysis and presentation of results are in two steps. In the first step, a statistical description of traits differences within the two disciplines (Medicine and Arts) is dis-cussed. In the second step, certain attitudes in library use are focused. In the results, expected patterns among student in two discipline areas found in personal traits and attitudes or mode of library use are presented. Finally, generalized solutions are proposed to overcome the existing problems and issues.

\section{Previous studies}

Library use affect from structural, cultural, personal, situational and behavioral aspects of contextual situation which makes a deep impact on library user (Talija et.al., 1999). Several studies have found that libraries are partly utilized by the users due to various aspects of contextual situations (Reneker, 1992). As a result, out to have very similar characteristics in traits and displayed most pronounce diversity in library use. There are significant differences in the attitude of library use by discipline. Need of library services by personal traits and attitudes in discipline context are highly required. Incorporating these findings with the existing libraries or ameliorating the services in general has a practical impact on utmost user satisfaction article.

Keywords: Discipline Context; Personal Traits; Attitudes; Patterns of Library Use.

many researchers have taken contextual approaches to investigate the patterns of library use from different angles and avenues. Palmer (1991), found a few differences among biochemists, entomologists, and statisticians according the disciplines and activities in information searching. Segments of library users (nonseekers, wide rangers, self-conscious seekers, confident collectors, and hunters) were identified. Statisticians were emerged as the non-seekers and wide rangers. Biochemists, entomologists, and statistician were prominent as unsettles. Confident collectors are mainly Entomologists. Biochemists behaved as Hunters. Results proved that information behavior was highly affected by the discipline areas of learning. Therefore, this paper anticipated that discipline context is as a good parameter to identify the library use pat-terns in deeper level.( Clougherty et.al., 1998), "The University of Iowa Libraries' Undergraduate User Needs Assessment" measured the impact of libraries on its users. Undergraduates' use of library sources and services, type of library services, resources, important facilities, perceptions of resources, satisfaction on resources and services. The study indicated that students are highly patterned in discipline context in these areas. Hiller (2002) "How important the University of Washington libraries are among different disciplines areas of students" focused to investigate whether the students are same or divers in library use in different discipline areas. The purposes of library visit have both identical and significant differences between academic areas. But importance of the libraries did not show significant differences among disciplines. Variables like priorities, 
purposes, physical visits to the library, use of resources, ways of catalog use and impact of new technologies were the most pronounced differences. Science, Engineering, and Health Science students use the library off campus. Humanities and Social Sciences are in campus users. The electronic and print journals are highly used than books and archival resources among Science and Engineering students. There is a correlation between the importance of resource types and the level of satisfaction with the available resources. Hiller's findings of patterns in libraries show diversities in discipline context. But it alone did not show up the impact of personal traits and attributes. Hiller's angle has impact on resources preferences widely. (Rowlands et.al. 2008). A web survey was conducted to identify "Understanding Information Behavior: How Do Students and Faculty Find Books?” at the University College London. Academic community in eight discipline areas (Arts and Humanities, The Built Environment, Engineering Sciences, Law, Life Sciences, Maths and Physical Sciences, Medical and Clinical Sciences, Social and Historical Sciences) was strikingly patterned in library use.

The previous researches which were selected above proved that library use takes different patterns from different areas such as usage, purposes, academic years, and discipline. Although, the approach is very common, a few prior researches have explained the relationships between the personal traits and attitudes in discipline context. Palmer found clusters of groups from student's subject's areas and communication. Hiller found different patterns of library use among different disciplines areas of students. Those analyses revealed that students had different patterns in libraries in relation to their academic areas. Hence, this paper has taken discipline context for identifying whether the personal traits and attitudes or mode of library use differ from discipline context from a new angle.

\section{Research questions}

It seems that undergraduates' behavior in libraries differs from one another and some individuals are par better than others. How this excellence occurs is a problematic issue to address. Is this based on the capacity of individuals or the areas of learning? Once, author of this paper, Karunanayake et al, (2014) reviled this issue from individual point of view. Students who have high abilities use libraries comfortably and some have difficulties in accessing and utilizing the available library services. Such experiences might be occurred not only individual basis. But also depend on the nature of the disciplines. If so, does the discipline context make discrepancies among students’ library use?
3.1 Concepts of discipline context, personal traits, attitudes

Students are diverse in library use. Is this difference of library use are related in some extent with differences of discipline context? Discipline context simply may not affect practices of library use. Factors such as personal traits and attitudes in library use might make huge impact on discipline context. The personal traits (Knowledge and skill traits) of utilizing library services are constructed socially and culturally. Knowledge trait represents the students' level of knowledge or experience and skill trait indicates the capacity or ability of search. In addition to that, a practice of library use is related with attitudes on library use. It might be expected that there exist some differences in attitudes on library use among students in different areas of disciplines. It might be also happened that there exist some diversities in library use pattern among students within the same discipline. A detailed research results on personal traits, attitudes and its relationships with discipline context is expected to be divers. In this context, this paper sets methodological and theoretical relationships among these three elements.

\section{Methodology}

The objectives are:

1) Do the personal traits differ among students in different disciplines?

2) Do significant difference is existed between the disciplines and attitudes or Modes of library use?

\subsection{The Research Method}

Objectives cover two kinds of variables, personal traits and attitudes in relation to library use in discipline context. The survey questionnaire was constructed to estimate these variables in two steps. To achieve the objective one, "Do the personal traits differ among students in different disciplines?” A conceptual framework was prepared which included twelve variables in a general library use process based on practical issues observed by the author.

The survey questionnaire included another set of six attitudes in library use (usage of information grounds; efficacy of search; resource preferences; attitudes on library collection; information need situations; alternative strategies, and query formulation) in library use as in Table I to clarify "Do significant difference existed between the discipline and attitude or mode of library use? This paper assesses the relationships between the disciplines and six selected attitudes or mode of library use. Relationships are explored based on individual students who are prescribed as belonging to two disciplines. Accordingly, library use pattern are depicted based on discipline and related attitudes. A selfadministered questionnaire was delivered among undergraduates of the Faculty of Medicine and Faculty of 
Arts of the University of Colombo- Sri Lanka who may be assumed with unique academic search perceptions and tasks.

\begin{tabular}{|c|c|}
\hline $\begin{array}{l}\text { Twelve Variables of } \\
\text { Personal Traits in Library } \\
\text { Use }\end{array}$ & Nine Attitudes in Library Use \\
\hline $\begin{array}{l}\text { 1. Knowledge of Search } \\
\text { Experience }\end{array}$ & $\begin{array}{l}\text { 1. Usage of Information } \\
\text { Grounds }\end{array}$ \\
\hline 2. Skill of Search Strategy & 2. Accesses to Library \\
\hline
\end{tabular}

4. Skill of unknown Search 4 Access to Information Terms

Resources

\begin{tabular}{lll}
\hline $\begin{array}{l}\text { 5. Knowledge of Suggested } \\
\text { Services }\end{array}$ & $\begin{array}{l}5 . \quad \text { Formal } \\
\text { Preferences }\end{array}$ & Resource \\
\hline 6. Negotiation Skill & $\begin{array}{l}\text { 6. Semi-Formal } \\
\text { Preferences }\end{array}$ & Resource \\
& &
\end{tabular}

7. Navigational Ability to 7 Information Need Situations Materials

\begin{tabular}{lrl}
\hline 8.Knowledge & of & 8. Dependency or Alternative \\
Discovering Materials & & Strategies
\end{tabular}

9. Knowledge of Material 9. Expectations or Query Setting $\quad$ Formulation

10.Navigational Ability to Information

11. Potential Information

Needs

12. Judgments About the

Self

Table I. Variables of Twelve Personal Traits and Nine Attitudes in Library Use.

Data comprised of different types of numerical values interpreted by a descriptive and inferential statistical methods. Firstly, descriptive method used to measure the personal traits by mean values between disciplines. Inferential statistical analysis such as Chi-square tests and ANOVA (one way analyses of variance) are applied to test the statistically significant relationship of the six attitudes. In order to explain results, it begins with the general description of responses by students to twelve information incidents by discipline wise. Then, relationships between the disciplines and attitudes will be explored. For each attitude, detailed explanation of statistics and differences will be given. Lastly, research objectives one and two are discussed collectively.

\section{Results}

Analyzed data are presented as follows: Descriptive Analysis of Personal Traits (Twelve variables) by Disciplines; Significant Deference of Six Attitudes or
Mode of Library by Disciplines; Usage of Information Grounds; Information Search Efficacy; Accesses to Library (physical searching); Access to Catalogue (physical searching); Access to Information Resources (intellectual searching); Resource Preferences; Formal Resource Preferences; Semi Formal Resource Preferences; Affective Situation or Information Need Situations; Dependency or Alternative Strategies; Expectations or Query Formulation; Library Use by Discipline Context.

5.1 Descriptive analysis of personal traits (twelve variables) by discipline

Mean calculation was used to measure the levels of the addressed twelve variables which represents the personal traits by two disciplines. Undergraduates' personal traits in library use were shown to be different by their learning aspects. Mean Levels of each incident state the undergraduates' positions in the search process. It measured how users behaved in the information search process in libraries. The results of how K\&S influences the users' performances are given in Table II.

\begin{tabular}{|l|c|c|c|c|c|c|}
\hline \multirow{2}{*}{ Twelve Information Incidents } & \multicolumn{6}{|c|}{ Total Respondents n=254 } \\
\cline { 2 - 8 } & \multicolumn{3}{|c|}{ Medical students: 128} & \multicolumn{3}{c|}{ Art Students: 126} \\
\cline { 2 - 7 } & $\mathrm{n}$ & Mean & SD & $\mathrm{n}$ & Mean & SD \\
\hline Knowledge of Search experience & 128 & 3.63 & 1.75 & 126 & 3.08 & 1.54 \\
\hline Skill of Search Strategy & 128 & 3.97 & 1.20 & 126 & 3.75 & 1.41 \\
\hline awareness of Digital resources & 128 & 4.02 & 1.52 & 126 & 3.64 & 1.55 \\
\hline Skill of Unknown search Terms & 128 & 5.02 & 1.69 & 126 & 5.36 & 1.57 \\
\hline knowledge of Suggested services & 128 & 3.54 & 1.15 & 126 & 3.64 & 1.45 \\
\hline Negitiation Skills & 128 & 3.79 & 1.41 & 126 & 4.17 & 1.58 \\
\hline Navigational Ability to Materials & 128 & 3.44 & 1.68 & 126 & 4.51 & 0.94 \\
\hline Knowledge of Discovering Materials & 128 & 2.32 & 1.46 & 126 & 2.64 & 1.70 \\
\hline Knowledge of Material Setting & 128 & 4.78 & 1.67 & 126 & 5.33 & 1.47 \\
\hline Navigational Abilitry to Information & 128 & 3.98 & 1.47 & 126 & 5.37 & 1.12 \\
\hline Potential Information Needs & 128 & 5.02 & 1.28 & 126 & 4.29 & 1.01 \\
\hline Judgements About the Self & 128 & 2.80 & 1.38 & 126 & 2.59 & 1.20 \\
\hline
\end{tabular}

Table II - Presentation of the Mean Scores of the Twelve Information Incidents between Two Disciplines (Medical \& Arts)

The knowledge and skill patterns recorded in Table II are presented in (Figure 1) indicating the patterns of library use by two disciplines.

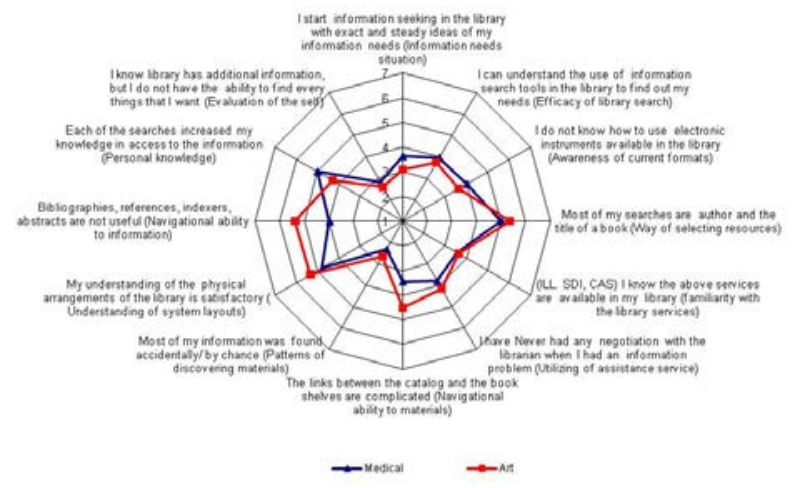

Figure 1 - Presentation of the Mean Scores of the Twelve Information Incidents between the Two Disciplines (Medical \& Arts) 
The findings suggest that, undergraduates' actual information search behavior was shown to be different by their personal traits in terms of knowledge and skill among learning disciplines. A consideration of the mean average makes it clear that levels of the (K\&S) limited the potential effectiveness in the process of information search and made them different. Based on the findings, the information search process may not be positively motivated by personal traits. The students in the two discipline areas turned out to have very similar characteristics in some incidents and displayed diversity in several incidents in library use. But, on the whole, students in both disciplines who show some differences of traits ability are equally prominent. Often some differences of traits are the same during the whole process. These differences indicated how personal traits cope with influencing the process of information search in libraries by discipline wise.

\subsection{Significant deference of attitudes/mode of library by disciplines}

The relationships between discipline and six attitudes or mode of library use were examined. Students were cross-tabulated by subjects and choices of each attitude and Chi square testing was conducted for difference between subjects, or means of each choices of attitude were compared between subjects using one way analysis of variance.

\subsubsection{Usage of information grounds}

It was assumed that the undergraduates usually use multiple information providers such as university libraries or city libraries which are easily and quickly accessible. Perhaps very important information grounds such as government agencies and professional institutes, (which are not easily accessible), may be rarely used. Each of the grounds has its own clients and characteristics, such as different types of information, methods of accessibility, restrictions and communication barriers. The patterns of information searching among the undergraduates could be noted by the grounds of information that they believe are important to their learning activities. Also, the links between the individual's interest and the information grounds will be expressed by their wider interests in the process of the information search. The surveyed respondents of the two disciplines which were expected to use different kinds of information grounds were asked to rank at least three important information grounds according to their preferences by using 1.2.3., whereby " 1 ” denotes highest agreement. Very limited six options such as “central library collection”, "faculty library collection”, "city library collection”, "collections of government agencies”, "collections of professional institutes" and "use of own collections" were given to prioritize and to ascertain whether the respondents have used one or multiple information grounds in their learning since they are the most useful grounds as assumed by the researcher. Medical students heavily rely on materials available in the faculty library and selected with 100\% higher demand as the first place of information. The reason may be quick accessibility and availability of in-depth information within a particular subject area. The other preferences explained somewhat different links with the information grounds. They maintained personal collections to receive secondary information, while referring to some information available in the related subjects' areas in the collection of the central library as the third place of information. The "city library collection" came as the fourth place as source of information while they rarely used "collections of government agencies and professional institutes” for getting information. For art students, the collection of the university library was the better ground of information while they use the city library as their second ground of information. They use their own collections as the third place for information. It is often the case that the collections of city libraries have a great deal of diversity of information for art students. Art students have shown more of a positive interest in city libraries than medical students. The collections of university libraries were the better grounds of information for both disciplines. Their own collections were the second most useful information ground for medical students. There was more of a negative interest amongst medical students towards government and professional collections than amongst art students, whereas city libraries have received more positive attention from art students than from medical students. Also, there were significant differences between medical and art students when they used the central library $\left(\mathrm{p}=.000^{* *}\right)$, city library $\left(\mathrm{p}=.000^{* *}\right)$, government collection $\left(\mathrm{p}=.003^{* *}\right)$, and also professional institutes $\left(\mathrm{p}=.002^{* *}\right)$. There was no considerable interest and diversity in using information available in information grounds other than university libraries.

\subsubsection{Information Search Efficacy}

The total access performances of both the physical and intellectual information search patterns of undergraduates were identified. The patterns of search efficacy used to predict the individual differences by disciplines. The possible relationships among the categories may display possible interest and will reflect more paucity areas in their search abilities since some students seems to be widely unsuccessful in their attempts to retrieve information within the search process. Hence, the user-designated search patterns or methods of conducting information searches, [(2A) how students access the library (physical searching), (2B) the ways in which students use the catalogue (physical searching), and (2C) the ways of accessing the found documents (intellectual searching)] are examined. The 
three categories which are coupled with specific bibliographic search terms and tools ranging from widely known (user known) to unknown (system terms) were given for ranking by using 1.2.3 etc. Each term represents widely used access methods in the each category. (2A) Accesses to Library: The expected six options are of the question No. 2A is (Library catalogue (Card), Library catalogue (Online), Browsing book shelves, Library staff, Colleagues, Teachers). The first and second options are geared to identifying the system or formal involvement and how far it works as methods of accessing the library. Option three is attempting to cover the self-interest or informal involvement, whilst the other three options cover interpersonal involvements. Online catalogue was the most often used method to access the library within both discipline with the highest overall usage of 93\% (119) by medical students compared to $73 \%$ (92) by art students. Both disciplines have a strong preference for using the online catalogue. The second most popular method of access to the library was browsing through book shelves and it has been shown to be a common habit of all of the students without creating any significant behavioral differences between disciplines. Browsing and picking up the relevant materials from book shelves is still very popular. With an equal proportion, the third access method of the users in both disciplines was obtaining the intervention of the library staff as well as support from colleagues. Although teachers were very effective in aiding the learning process, students did not rank the teachers' role in supporting library access so highly. Teachers played more of a passive role in the case of medical students than was the case for art students but remained as the least, useful human interveners. Significant differences were found (Card catalog $\left(\mathrm{p}=.001^{* *}\right)$, Online catalog $\left(\mathrm{p}=.000^{* *}\right)$, Browsing book selves $\left(\mathrm{p}=.027^{* *}\right)$, Through library staff $\left(\mathrm{p}=.026^{* *}\right)$, College $(p=.118 * *)$, Teachers $(p=.000 * *)$. (2B) Access to Catalogue (physical searching): When comparing the search efficacy on finding the information materials available in the library by using four terms (Author, Title, Subject headings, Classification number) study found that there are no big differences between disciplines. The most popular search terms are author $(p=.529)$ and the title $(\mathrm{p}=.451)$ of the documents. There were no significant differences between the two subjects in accessing the catalogue except for the use of class numbers $\left(p=.012^{* *}\right)$. They depend on their own search terms than unknown search terms. (2C) Accesses to Information Resources (intellectual searching): Patterns of information selection from found materials were measured by using (Table of content, Abstract, Indexes, Bibliographies, References, Glossaries) There were no dissimilarities between the two subject settings relative to the several search patterns when finding information within the found documents. The patterns of use of content notes, use of indexes, use of bibliographies and references have indicated a similar average of mean levels between the subjects. But statistically significant difference was found in the usage of abstracts $\left(\mathrm{p}=.002^{* *}\right)$, indexes $\left(\mathrm{p}=.005^{* *}\right)$ and glossaries $\left(\mathrm{p}=.000^{* *}\right)$ be-tween subjects.

\subsubsection{Information resource preferences}

The characteristics of information resources used by the respondents in utilizing those resources were examined. On the subject of resource preferences, respondents were asked to rank their preferences by using 1.2.3 etc. The results provide useful guidance to identify source preferences while explaining the users' information needs and the resources which they used. The types of materials used may vary according to the nature of their learning activities, discipline, and level of their preferences. But it is expected that there are very significant differences between the subjects they learned. Affected variables of source preferences may be not only convenience and ease of accessibility but sometimes may also be personal interest. The materials which are commonly used and available in libraries were referred to as the following two basic categories; formal sources, (printed books, periodicals/journals, abstract journals, reviews/bulletins, maps/guides/handbooks, dictionaries/encyclopedias, bibliographies/indexers) and semi-formal sources, (pamphlets, reports, conference papers, government documents, dissertations/ thesis) were sub grouped. All of the above types of information, appearing in two different categories, were considered as very important formats for academic learning. The use of the above categories has been cited in the research field for many years.

Formal resource preferences: the utilization of resources was different according to the disciplines. Books were the most heavily used materials for art students and medical students, followed by ready reference materials and periodicals respectively. Art students used very specific information from ready reference materials while medical students rarely referred to that information. More than two thirds of students in both disciplines did not rank or assign any value to the remaining sources as being useful. As above, the medical students' use of abstract journals seems to be much wider than that of art students and they depended on simplified information in periodicals. Also, a demand for information from maps/ guides and ready reference materials was higher among the art students. Overall, the resources which the students in the two disciplines favored indicated significant differences. Almost all of the students preferred printed books. There were significant differences between the two disciplines in the use of format of the formal resources. Among formal resources, medical students have stated high preference for printed books or periodicals as their main resources for information. Third priority was given to the abstract 
journal. Their next preference was for ready reference materials, bibliographies \& indexes respectively. Information in re-views/bulletins and maps/guides were not useful for medical students.

Semi-formal resource preferences: In the case of semiformal resources, the common use of dissertations/ theses and reports was reported by medical students.

Art students reported a higher preference for the available information of government documents, reports and pamphlet collections rather than dissertations and theses respectively. Pamphlets seemed to be useful for art students to some extent as their third most important resource. However, the students of medical science were fully aware regarding the use of information in pamphlets. They relied on information in conference papers to some extent while choosing it as their third most useful resource as opposed to art students who completely rejected it as the least useful resource for them. Overall, the usages of resources were extremely significant between the two subjects. Different patterns of source usage of the students come from two disciplines settings indicated the required resource types for their information. (Pamphlets $\left(\mathrm{P}=.000^{* *}\right)$, Project reports $\left(p=.000^{* *}\right)$, Conference papers $\left(p=.000^{* *}\right)$ Government documents $\left(\mathrm{p}=.000^{* *}\right)$ Dissertation and Thesis $\left(\mathrm{p}=.000^{* *}\right)$. It highlighted some of the precautions which information providers should consider when doing collection developments. Individuals' information resource preferences in those two subjects' settings were somewhat varied, comparatively showed significant differences. Some vital information materials of semi-formal resources were underscored by medical students. Coverage, availability and accessibility of formal resources may be the reason for higher utilization. The two disciplines settings may need different kinds of materials to meet their information needs.

\subsubsection{Affective Situation or Information Need Situation}

On the information need situations, respondents were asked to report on their level of satisfaction with the library collection and on their ability to find information to meet their needs. This was assessed by "Please rate your satisfaction with the information available in the library for the following academic information needs". Information need situations that were specially chosen included: "for recommended reading”, "for preparing topic assignments", "for compulsory reading", "for auxiliary reading”, "for thesis writing". The aspects of information need situation specifically addressed to understand their affective situation on the collection and their ability to find the information they required. Many students expressed different levels of anxiety on the collection. The level of satisfaction within the information needs situations differed between the two subjects' settings. The medical students had a positive response in the case of in- formation "for recommended reading, "for compulsory reading", "for dissertations", "for thesis writing" and "for topic assignments". Overall satisfaction towards the information available in the library was almost all positive (except "for auxiliary reading"). The negative feeling can be recognized as being related to the specialization of the subject coverage. The medical students have intensity for auxiliary reading as far as subjects' related information.

Almost all of the art students expressed satisfaction with the information they found "for auxiliary reading" and "for recommended reading". Their highest level of dissatisfaction was with information "for compulsory readings". There were significant differences between medical and art students concerning information on "compulsory reading $(\mathrm{p}=.000 * *)$, auxiliary reading $\left(\mathrm{p}=000^{* *}\right)$, and information needed for thesis writing $\left(p=.003^{* *}\right)$ ". In summary, the respondents' levels of satisfaction for most of information need situations are significantly different according to the nature of their subject specialization. Significant differences were found between the two subject areas, particularly in compulsory reading, (where the medical students were highly satisfied but the art students were highly dissatisfied), auxiliary reading (the medical students were highly dissatisfied but the art students were highly satisfied), and for thesis writing (where the art students were highly dissatisfied) Information satisfaction differed between the subjects. The medical students expressed a greater degree of satisfaction than art students in each information needs situation except for auxiliary reading. The art students asked for more information on the coverage of subjects than medical students.

\subsubsection{Dependency or Alternative Strategies}

When examined the five alternative strategies such as (depend on catalog, auxiliary resources, librarian, library staff, give up the search), patterns of dependency in the information search process in relation to the search strategies of medical and art students have subtle differences. Medical students have a higher tendency to use other resources, a willingness to stay in the search process, a stronger tendency to contact library staff, search catalogues and meet the librarian. In the same way, the art students' patterns indicated that they often contact the library staff, have a reliance on the catalogue, are less likely to abandon the search, are likely to look for alternative resources and communicate with the librarian. There was a significant difference between the two subject settings when using other resources $(p=.015)$. A willingness to stay in the search process and look for other resources were the most commonly selected alternative strategies within both disciplines. Relying on catalogues and seeking help from the library staff were also frequently cited. Dependency on the librarian for information was very limited. There was no sign of students looking for in- 
formation entire-ly by themselves since there was a high tendency to ask the library staff for help. Use of other resources and seeking help from the library staff was also preferred more by the medical students than by the art students. There was a lower tendency to consult the librarian for the required information for both disciplines.

\subsubsection{Expectations or Query Formulation}

Regarding the six expectation of (information on discipline, find resource, library services, locate material, catalog use, library equipment) there found that different expectations between discipline. Medical students mostly made regular queries for information on library services and for guidance to find relevant resources. Art students expected assistance to use library services, guidance to find resources and personal help to locate materials from the shelves. The weighted means of the six aspects between the two disciplines indicated that medical students have the ability to find materials from the shelves to a greater extent than art students. That may be due to limitations of subject coverage. There were significant differences in the patterns of query formulation between the two subjects. Information on discipline $\left(p^{=.001 * *}\right)$, Guidance for locating materials $\left(\mathrm{p}=.001\right.$, Information on library services $\left(\mathrm{P}=.000^{* *}\right)$, Use of library equipment $\left(\mathrm{p}=.004^{* *}\right)$. Relationships between subjects and attitudes analyzed and summarized by statistical significance are givens in Table III (in Appendix).

\subsection{Students' patterns of library use by discipline}

A couple of library use pattern are derived from a set of personal traits and a set of attitudes which affect practices of library use between two discipline areas of learning among university undergraduates. In the point of personal traits, students responded in a varied manner but their knowledge and skill had an impact from discipline. Often some differences of traits are the same during the whole process. These differences indicated how personal traits cope with influencing the process of information search in libraries by discipline wise. These results answered the first research objective 1 "Do the personal traits differ among students in different disciplines?”

The answer to the second objective, "Do significant difference exist between the discipline and attitude or Mode of library use?” In around half of items of attitudes, Usage of information grounds; Access ways to the library; Access ways to the information resources, Resource preference, and expectation (patterns of query formulation), two disciplines showed significant differences. In regard to satisfaction on the library collection and satisfaction on information need situations, subjects also showed significant differences. List of attitude indicates that there exist some library use pat- terns and that they are which are closely related to disciplines.

\section{Conclusions}

In the Different patterns of library use were targeted from discipline context. Relationships between twelve personal traits and six attitudes on library use were checked. Significant relationships were found indicating that students of a discipline have common tendencies (common library use pattern). As universities, libraries and students are all generally diversified. It is very probable that university students using library may also be diversified. For the utmost users' satisfaction, Libraries have to take precautionary actions by incorporating with the above findings in general. This paper generates library use patterns with regard to discipline context by two disciplines relating to personal traits and attitudes. Identification of such patterns is a prerequisite for the development of libraries and can be of practical importance to designing user oriented library services.

\section{References}

Clougherty, L; Forys, J; Lyles, T; Persson, D; Wal-ters, C; Washington-Hoagland, C (1998). The University of Iowa Libraries' undergraduate user needs assessment // College \& Research Libraries, 59 : 6 (1998) 571-583.

Hiller, S. (2002). How Different Are They? A Comparison By Academic Area Of Library Use, Priorities, and Information Needs at the University of Washington // Issues in Science and Technology Librarianship 33. http://www,ist.org/02-winter/article.html.

Karunanayake, K. G. D. A.; Haruki N (2014). Four Types of Undergraduate Library Users, Based on Their Profile of Library Use, Knowledge and Perceptions // LIBRES: Library \& Information Science Research Electronic Journal 24: 1 (2014).

Palmer, J (1991). Scientists and information: I. Using cluster analysis to identify information style. // Journal of Documentation 47:2 (1991) 105-129.

Reneker, M. (1992). Information-seeking among of an academic community. DLS thesis // PhD dissertation, Columbia University.

Rowlands, I; David N (2008). Understanding information behaviour: how do students and faculty find books? // The Journal of Academic Librarianship 34: 1 (2008) 3-15.

Talja, S; Heidi K; Pietiläinen, T (1999). The production of 'context'in in-formation seeking research: a metatheoretical view // Information Processing \& Management, 35: 6 (1999) 751-763.

Copyright: (C) 2016 Karunanayake. This is an openaccess article distributed under the terms of the Creative Commons CC Attribution-ShareAlike (CC BYSA), which permits use, distribution, and reproduction in any medium, under the identical terms, and provided the original author and source are credited.

Received: 2015-06-17. Accepted: 2016-04-01 
Appendix 1

\begin{tabular}{|c|c|c|c|}
\hline \multirow{2}{*}{$\begin{array}{l}\text { Categories of } \\
\text { attitude }\end{array}$} & \multicolumn{3}{|c|}{ Item in category of attitude } \\
\hline & Significant difference foun & & No significant difference found \\
\hline \multirow{4}{*}{$\begin{array}{l}\text { 1.Usage of } \\
\text { information } \\
\text { grounds }\end{array}$} & University central library & Govemment collections $^{24}$ & \multirow{4}{*}{$\begin{array}{l}\text { Medical faculty Lbrary, personal } \\
\text { collections }\end{array}$} \\
\hline & & & \\
\hline & Medical faculty Library & Professional institutes & \\
\hline & City horary ${ }^{24}$ & & \\
\hline \multicolumn{4}{|l|}{$\begin{array}{l}\text { 2. information } \\
\text { search efficacy }\end{array}$} \\
\hline \multirow{3}{*}{$\begin{array}{l}\text { 2-1.Access ways } \\
\text { to the library }\end{array}$} & Card catalogen & Browsing book shelves ${ }^{\circ 4}$ & \\
\hline & Online catalog & Through Library stafit" & \\
\hline & Collexgue & Teachers" ${ }^{-4}$ & \\
\hline $\begin{array}{l}2-2 \text { Acess to } \\
\text { catalog }\end{array}$ & \multicolumn{2}{|l|}{ Class numbers" } & Authors, Titles, Subject headings \\
\hline \multirow{2}{*}{$\begin{array}{l}2-3 . \text { Access to } \\
\text { resources }\end{array}$} & Content of the document" & Inderves" & \multirow[b]{2}{*}{ Bibliographies, References } \\
\hline & Abstracts ${ }^{44}$ & Glosanies"4 & \\
\hline \multicolumn{4}{|l|}{$\begin{array}{l}\text { 3.Resources } \\
\text { preference }\end{array}$} \\
\hline \multirow{3}{*}{$\begin{array}{l}\text { 3-1.Formal } \\
\text { resources }\end{array}$} & Periodicale Joumals" & Dictionaries/Encyclopedias & \multirow{3}{*}{ Printed books, Reviews/Bulletins } \\
\hline & Abstract ${ }^{26}$ & Bibliographies/Indentes"4 & \\
\hline & $\begin{array}{l}\text { Maps } \\
\text { /guides/Handbooks** }\end{array}$ & & \\
\hline \multirow{3}{*}{$\begin{array}{l}\text { 3-2.Semi-formal } \\
\text { resources }\end{array}$} & Pamphlets" & Govemment documerts & \\
\hline & Project reports ${ }^{40}$ & Dissertation thesis" & \\
\hline & Conferences papers" & & \\
\hline \multirow{2}{*}{$\begin{array}{l}\text { 4.szifiaction on } \\
\text { information } \\
\text { needs gituations }\end{array}$} & $\begin{array}{l}\text { For compulsory readings } \\
\text { * }\end{array}$ & For disertation thesi. ${ }^{47}$ & \multirow[t]{2}{*}{$\begin{array}{l}\text { For class work course readings, } \\
\text { For assignments papers reports }\end{array}$} \\
\hline & For auriliary readings ${ }^{* 4}$ & & \\
\hline $\begin{array}{l}\text { 5.Pattems of } \\
\text { dependency }\end{array}$ & $\begin{array}{l}\text { Dependency on other } \\
\text { resources"* }\end{array}$ & & $\begin{array}{l}\text { Dependency on catalog. } \\
\text { Dependency on librarian } \\
\text { Dependency on libray staff } \\
\text { Abundance of search }\end{array}$ \\
\hline \multirow{2}{*}{$\begin{array}{l}\text { 6.Expectations or } \\
\text { pattems of query } \\
\text { formulation }\end{array}$} & $\begin{array}{l}\text { Guidance for locating } \\
\text { materials } * *\end{array}$ & Infonmation on disciplipe & \multirow[t]{2}{*}{$\begin{array}{l}\text { Assistant of idertify resources, } \\
\text { use of online catalog }\end{array}$} \\
\hline & $\begin{array}{l}\text { Infonmation on library } \\
\text { Services** }\end{array}$ & Use of tibrary equipmente & \\
\hline
\end{tabular}

- Indicates unavailable by indifference, $\mathrm{x}$ - no difference,

* Significant at 5\% and ** Significant at 1\%

Table III - Presentation of the Mean Scores of the Twelve Information Incidents between Two Disciplines (Medical \& Arts) 